\title{
Afterlives of the Republic of Letters \\ Learned Journals and Scholarly Community in the Early Nineteenth Century
}

\author{
Floris Solleveld ${ }^{1}$ \\ Department of History, KU Leuven
}

\begin{abstract}
What happened to the Republic of Letters? Its history seems to stop at the end of the eighteenth century. And yet, in the nineteenth century, there still existed a community gathered in scholarly societies, maintaining a transnational correspondence network and filling learned journals. The term indeed becomes less frequent, but does not go entirely out of use. This article traces the afterlives of the Republic of Letters in the early nineteenth century. Specifically, it investigates texts that attempt to (re)define the Republic of Letters or a cognate, the wider diffusion of the term, and the changing role of learned journals in that period. While most attempts to reinvent the Republic of Letters failed miserably, they indicate a diagnosis of the state of learning and the position of scholars in a period of transition, and in doing so they contradict an 'unpolitical' conception of the Republic of Letters.
\end{abstract}

Keywords: Republic of Letters, nineteenth century, learned journals, romanticism, Abbé Grégoire, Jahrbücher für wissenschaftliche Kritik, Edinburgh Review

In January 1803, the second volume of the Edinburgh Review opened with a review of Charles de Villers's Philosophie de Kant. It began by reflecting on the state of the scholarly community and scholarly communication, and did so rather sceptically:

...It has been a customary form of thought to consider the sciences as refusing each geographical barrier; and we have heard of the Republic of Letters, till we almost believe it to exist. [...] We willingly forget, that the Great Republic, one and indivisible, has in truth almost as many divisions, with mutual jealousies and mutual ignorance, as the political relations which it comprehends [...] and, though we will not say with the commentator of Kant, that it is as difficult for any good book, to effect a passage over the Rhine, as for the whole Austrian army, we own that a system of metaphysics is of almost as difficult transportation. ${ }^{2}$

\footnotetext{
${ }^{1}$ Research for this article was mainly carried out at Research Centre Gotha, University of Erfurt and made possible by a Herzog-Ernst-Stipendium of the Fritz-Thyssen-Stiftung. I wish to thank Dirk van Miert, René Koekkoek, Olaf Simons, the editor, and two anonymous reviewers.

2 'Villers, Philosophie de Kant', Edinburgh Review 2 (January 1803), 253-280: 253
} 
With regard to the reception of Kant, the editors unintentionally proved their point, for little was heard about Kant in Britain in the following decade; the Institut National in Paris, to which Villers had dedicated his work, responded lukewarmly as well. But as a statement about the Republic of Letters, it proved something of a pragmatic paradox, since the article was itself the Republic of Letters in nuce: a British journal presenting the ideas of a Prussian philosopher as communicated by a Frenchman in Göttingen. Moreover, this was a journal that after two years boasted 15,000 readers, and attained such an audience with long reviews that were essayistic rather than technical, often discussing several books in tandem. The journal's editors may be considered as the originators of the review essay. ${ }^{3}$

The skepticism expressed by the Edinburgh Review was not new; complaints about the Republic of Letters are as old as the Republic itself. But it still may strike the modern reader as odd, since not much is heard about the Republic of Letters after the French Revolution. The great digital repositories of Stanford's Mapping the Republic of Letters and Oxford's Electronic Enlightenment stop at the end of the eighteenth century, as does the Dictionnaire des Journaux 1600-1789. While it is impossible to write the intellectual history of the eighteenth century without recourse to the notion of the 'Republic of Letters', it is difficult to find the term in work about the nineteenth century. ${ }^{4}$ Judging by the secondary literature on the Republic of Letters, it seems as if it had faded into thin air.

What happened to the Republic of Letters? It was, of course, always an imagined community; ${ }^{5}$ and like all fictional entities it died when people ceased to believe in it, then died a second time when it ceased to be talked about. But it was also something more: a correspondence network connecting scholars across Europe and beyond, and a symbolic economy which traded in knowledge and prestige rather than in money and power. That correspondence network, and that symbolic economy, certainly did not end at the end of the eighteenth century; we still correspond, and we still don't get rich. Even the sense of a learned community is still with us, in spite of overstretch and segmentation. The term 'Republic of Letters' seems to become less frequent in the nineteenth century, but it does not entirely disappear from learned discourse either.

This article aims to fill a gap in the history of the Republic of Letters by charting its early nineteenth-century afterlives. It is concerned with three aspects: conceptualizations, phraseology, and the role of learned journals. By conceptualizations, I mean texts that have

\footnotetext{
${ }^{3}$ Cf. Christoph Groffy, Die Edinburgh Review, 1802-1825: Formen der Spätaufklärung (Heidelberg, 1981), 8

${ }^{4}$ A notable exception is Antoine Compagnon, La Troisième République des Lettres: De Flaubert à Proust (Paris, 1983), which, however, is silent about the 'Republic of Letters' as an actor's category. The phrase has been used for and in interwar literary networks: Compagnon (ed.), La République des Lettres dans la Tourmente (1919-1939) (Paris, 2011); Marleen Rensen, 'Restoring the Republic of Letters: Romain Rolland, Stefan Zweig and Transnational Community Building in Europe, 1914-34', in S. Couperus \& H. Kaal (eds.), (Re)Constructing Communities in Europe, 1918-1968: Senses of Belonging Below, Beyond and Within the Nation-State (New York, 2017), 153-74. A rather timeless notion of it is espoused in Pascale Casanova, La République mondiale des Lettres (Paris, 1999)

${ }^{5}$ Cf. Benedict Anderson, Imagined Communities: Reflections on the Origin and Spread of Nationalism (London, 1983), ch. 1. Anderson defines nations as 'imagined communities' held together mainly by print culture, of which most members have not actually met, but where, 'regardless of the actual inequality and exploitation that may prevail in each, the nation is always conceived as a deep, horizontal comradeship' (16). The most elaborate application of Anderson's concept to the early modern Republic of Letters is in Robert Mayhew, 'British Geography's Republic of Letters: Mapping an Imagined Community, 1600-1800', Journal of the History of Ideas 65 (2004), 251-76
} 
the Republic of Letters - or a cognate - as subject matter, of which I have traced a dozen. Phraseology covers the wider use and diffusion of the term Republic of Letters. Learned journals, in the early nineteenth century, merit particular attention because they still are organs of the learned world at large: they cover broad areas of scholarship and literature, link themselves to academies and learned societies, and keep track of foreign literature through reviews and notices. This is, in itself, an underexplored topic. Some journals, like the Edinburgh Review and the Revue des deux Mondes, do this while addressing a broader audience through a new type of journalistic essay which acquires the status of literary production in its own right.

Posed as a binary question, it is undecidable whether the Republic of Letters persisted in the nineteenth century. The commonwealth of learning was always an imperfectly realized ideal anyway. But the question still makes sense because it leads into a largely undiscovered province of the history of scholarship. The debate about the learned republic among early nineteenth-century scholars is not so much of a debate, because few of the texts relate to each other. Instead, they are part of the reconceptualization of the role of scholarship and the scholarly community in a period of seismic transition. Tracing the nineteenth-century afterlife of the Republic of Letters also allows us to shed light on that transition as a transnational process, highlighting international parallels and the role of learned journals. It is not, in other words, merely a semantic question.

Nor is the question entirely new. Three recent articles by Laurence Brockliss, Olaf Simons, and Peter Burke have touched upon it. Brockliss, at the end of an article on scholarly hierarchies in the late eighteenth century, suggests three explanations for the end of the Republic of Letters: explosion in the number of scholars, with increasing degrees of separation as the result; implosion through increasing specialization; and disruption caused by the French Revolution. ${ }^{6}$ In his 2004 monograph Calvet's Web, Brockliss describes in painstaking detail how the local correspondence network ('mini-Republic') of Avignon physician/collector Esprit Calvet was scattered, or even wiped out, by revolutionary turmoil and replaced by a new generation attached to state-sponsored institutions. ${ }^{7}$ Simons traces a change in the meaning of 'letters' or 'literature', from a container term for learning at large to literature as an art form. He suggests an 'unspectacular' answer: 'Die Frage nach dem Ende der frühneuzeitlichen Respublica Literaria kann man unspektakulär beantworten: Sie wich offensichtlich der modernen Scientific Community. ${ }^{, 8}$ At the same time, he describes the simultaneous emergence of a 'literary world', a world of poets, novelists, and reviewers instead of scholars and journalists. Burke, in a longue durée analysis of the Republic of Letters as a 'communication system', points out two main reasons: nationalism (including national audiences and institutions) and academic specialization. As a result, 'the phrase

\footnotetext{
${ }^{6}$ Laurence Brockliss, 'Starting-out, getting-on and becoming famous in the eighteenth-century Republic of Letters', in A. Holenstein, M. Steinke \& M. Stuber (eds.), Scholars in Action. The Practice of Knowledge and the Figure of the Savant in the eighteenth Century (Leiden, 2013), Vol. I, 71-100: 99-100

${ }^{7}$ Brockliss, Calvet's Web: Enlightenment and the Republic of Letters in Eighteenth-Century France (Oxford, 2004), ch. 7

${ }^{8}$ Olaf Simons, 'Von der Respublica Literaria zum Literaturstaat? Überlegungen zur Konstitution des Literarischen', in M. Füssel \& M. Mulsow (eds.) Aufklärung. Band 26: Gelehrtenrepublik (Hamburg, 2014), 291-330: 291
} 
république des lettres gradually became restricted to belles-lettres'. ${ }^{9}$ Still, according to Burke, a 'commonwealth of learning' continued to exist; if anything, scholarly communication and exchange intensified owing to steamships, international congresses, and faster, cheaper, more reliable postal services.

An earlier volume, Die europäische République des Lettres in der Zeit der Weimarer Klassik, based on a 2004 colloquium, emphasizes mainly the repressive role of Restoration politics and the nationalism and individualism of the Romantic movement, both presumably incompatible with the cosmopolitan spirit of the République. Thus Marc Fumaroli compares Chateaubriand and Goethe, and finds them representative of two conflicting attitudes: the Olympian cosmopolitanism and the enlightened classicism of Goethe and the permanent uprootedness and counter-Enlightenment irrationalism of Chateaubriand. ${ }^{10}$ Bernard Dieterle argues that the circle of Germaine de Staël in Coppet, in spite of its 'Communauté des esprits' and its international character, does not mark a re-foundation of the Republic of Letters: that simply was not part of de Staël's political and A.W. Schlegel's literary agendas. ${ }^{11}$ They were no longer writing for the learned republic, but for the literary world.

All that, however, does not preclude the survival of both the phrase and the infrastructure of the Republic of Letters into the nineteenth century. Infrastructural explanations are insufficient here. The number of academies and societies, vestiges of the eighteenth-century Republic of Letters, only continued to increase in the nineteenth century, while the number of universities was fairly stagnant until after mid-century. ${ }^{12}$ Research in the early eighteenth century had already been concentrated at universities in the German lands, while in other European countries, that process did not occur until around 1870, in tandem with the rise of professional journals. The situation in the world of learning in the first half of the nineteenth century is essentially undefined. It was no longer the Republic of Letters of the late Ancien Régime; yet it still existed as an imagined community, a symbolic economy, and a network of correspondence. And yet - this much is clear - all attempts to redefine the Republic of Letters in the early nineteenth century failed to achieve their ends.

One can add other explanations. There are indications of overstretch: the term République des Lettres already becomes less frequent in the second half of the eighteenth century, while the less committal Gens de Lettres does not. One significant economic factor to consider is the drastic increase in book production due to three technical innovations (woodpulp paper, stereotype printing, and the steam press) in the first decades of the nineteenth century, enabling authors to address a reading public wider than that of the imagined Republic. Appeals to the Republic of Letters become appeals to the nation. Politically, the French Revolution changed the connotations of the word 'Republic' - though that, as we shall see,

\footnotetext{
${ }^{9}$ Peter Burke, 'The Republic of Letters as a Communication System', Media History 18:3-4 (2012), 395-407: 397; cf. Dirk van Miert, 'What was the Republic of Letters? A brief introduction to a long history (1417-2008)', Groniek 204/205 (2016), 269-87: 278-9

${ }^{10}$ Marc Fumaroli, 'Chateaubriand et Goethe', in M. Knoche \& L. Ritter-Santini (eds.), Die europäische République des Lettres in der Zeit der Weimarer Klassik (Göttingen, 2007), 151-73

${ }^{11}$ Bernard Dieterle, 'Jenseits des Rheins: Germaine de Staël und August Wilhelm Schlegel', in ibid., 175-92

${ }^{12}$ An overview of learned societies until 1849 is on http://scholarly-societies.org [last modified 27 December 2009; since taken offline, but still accessible through the Internet Archive's Wayback Machine]. For the number of universities, see Christophe Charle, 'Patterns' in Walter Rüegg (ed.), A History of the University in Europe. Volume III: Universities in the Nineteenth and early Twentieth Centuries (1800-1945) (Cambridge, 2004), 33-80
} 
was not necessarily an impediment, since some revolutionary rhetoric is indeed subsumed in learned rhetoric. Finally, there is the fate of the parti philosophique, which dominates the Republic of Letters in the second half of the eighteenth century, which both fell victim to the Reign of Terror and are subsequently blamed for the Revolution. Taken together, these are too many explanations for explanatory elegance, but a smoking gun is unlikely to be found.

In what follows, my focus is on the French, English, and German language areas, which accounted for two-thirds of European book production in the late eighteenth century ${ }^{13}$ and continued to dominate nineteenth-century learned and literary life. This presents us with one case of dramatic political and institutional rupture (French), one of relative continuity (English), and one of rapid cultural rise (German). Developments in Italy and the Netherlands, centres of the Republic of Letters in earlier centuries, are less important beyond the national context for this period. More generally, while it is important to consider local/national differences in conceptualizing the world of letters, a Republic of Letters that persists only in local/national contexts is no longer one Republic.

\section{Conceptualizations}

In 1774, Friedrich Klopstock, then still the leading German poet, published a fictional, halfsatirical work Die teutsche Gelehrtenrepublik. It described the constitution of a Republic of Letters divided up into guilds with eldermen and journeymen, a populace of lesser authors and teachers, and below both, the literary rabble. After listing the learned guild's regulations and punishments, most of the book is filled with the proceedings of its Landtag, which takes place under an old oak. Among those condemned are philosophical system-builders, authors that write in Latin, followers of foreign fashions, and critics at large. Here and there, the proceedings are shot through with pieces of Klopstock's own poetry and essays. Towards the end, the Republic receives foreign emissaries, whose arrival causes great consternation. In an attempt to undermine the book market, and to raise more money, Klopstock's Gelehrtenrepublik was self-published, with over 3,000 subscriptions. ${ }^{14}$

Goethe recalls in Dichtung und Wahrheit how the German-reading public eagerly awaited the work, only to be confused and disappointed when it appeared. ${ }^{15}$ The confusion was at least Goethe's own, since his first response was elated ('Klopstock's herrliches Werk hat mir neues Leben in die Adern gegossen. [...] Denn hier fliesen die heiligen Quellen bildender Empfindung lauter aus vom Throne der Natur'), and one month later utterly dismissive ('Mit Klopstocks Gelehrten Republik ist die ganze Welt unzufrieden, es versteht sie kein Mensch'). ${ }^{16}$ We do not need to take Goethe's word for it, since Klopstock's Gelehrtenrepublik received only negative reviews, was rarely discussed in later years, was not

\footnotetext{
${ }^{13}$ Eltjo Buringh and Jan Luiten van Zanden, 'Charting the 'rise of the West'. Manuscripts and Printed Books in Europe, A long-term perspective from the sixth to the eighteenth centuries', Journal of Economic History 69:2 (2009), 409-45: 417

${ }^{14}$ Several figures are mentioned in the Apparat to Klopstock's collected works (Klopstock, Die deutsche Gelehrtenrepublik (Werke VII:2), ed. K. Hurlebusch (Berlin, 2003), 323, 326); Klopstock's own indication was 3,300 .

${ }^{15}$ J.W. Goethe, Aus meinem Leben. Dichtung und Wahrheit, Vol. III (Tübingen, 1814), 173ff

${ }^{16}$ Letters from June-July 1774, quoted in Klopstock, Werke VII:2, 336-7
} 
published again except as part of his collected works, and the projected second volume never followed. In short, it flopped.

It is not hard to see why the German reading public was confused. Klopstock's Gelehrtenrepublik is too noncommittal and too remote from reality to be a programmatic text, too satirical to be a utopia. As satire, it is rather pedantically unfunny; to boot, it insulted not just Klopstock's rivals but also his prospective reviewers, ${ }^{17}$ the leading German scholars at the University of Göttingen, and virtually all German philosophers. If it was intended as a foundational text, it is not clear what it wished to found. Though not a direct point of reference for later attempts to (re)define the Republic of Letters, it is a good starting point because it shows the difficulty of substantiating the imaginary Republic. Later attempts would likewise use political imagery that largely remained metaphorical, and they too, would invariably have no success. One possible conclusion is that the Republic of Letters was a notion best left functionally vague.

The most outspoken advocate of the Republic of Letters, in three treatises from three different decades, was the French revolutionary Henri (Abbé) Grégoire. The first of these treatises coincided with the re-opening of the Royal Academies as the Institut National in 1795, a significant moment in the re-conceptualization of the Republic of Letters. Grégoire was among the founding members of the new class of Sciences morales et politiques, and in that capacity he delivered a paper on how to improve the lot of mankind through what he called political or social science. The Institut National, he argued, could bring this about by rallying and organizing the correspondence network of the Republic of Letters:

Les savans, les gens de lettres et les artistes composent une famille éparse sur le globe, et plus unie par le cœur que par une correspondance régulière qui doubleroit leurs forces. (...) L'Institut national, en prenant l'initiative d'une correspondance qui sera, pour ainsi dire, l'annonce d'une croisade générale contre les préjugés, est loin d'ambitionner aucune suprématie. (...) La république des lettres enfantera des républiques. ${ }^{18}$

[Scholars, men of letters, and artists form a family spread over the globe, more united by heart than by regular correspondence which would double their forces. (...) The National Institute, in taking the initiative for an exchange of letters which will be, so to say, the proclamation of a general crusade against prejudice, is far from aspiring to any kind of supremacy. (...) The Republic of Letters will bring forth republics.]

The Institut National would indeed become, or rather re-emerge, as a centre of learned communication, with its members editing most of the leading French learned journals. This much of his prediction came to pass. The class of Sciences morales et politiques was later closed by Napoleon because he found its political theorizing a nuisance, and members, with

\footnotetext{
${ }^{17}$ Cf. Christian Hippe, 'Gelehrte Kürze. Zum Feindbild der Zeitschriften in Klopstock's Deutscher Gelehrtenrepublik', in U.J. Schneider (ed.), Kulturen des Wissens im 18. Jahrhundert (Berlin, 2008), 233-42

${ }^{18}$ Henri Grégoire, 'Réflexions extraites d'un ouvrage du citoyen Grégoire sur les moyens de perfectionner les sciences politiques', Mémoires de l'Institut national des Sciences et des Arts: Classe des Sciences morales et politiques, Vol. I (Paris, An VI [1798]), 552-66: 563-6
} 
the exception of the obstinate Abbé Grégoire, were relegated to other classes, Senate seats, and well-salaried sinecures. After Waterloo, Grégoire made a renewed appeal to the learned world to unite, but now to do so in the form of a triennial congress. The plan still was to morally improve mankind - with the inclusion of women and non-Europeans - but now without institutional support. To avoid royal patronage as well as despotic tendencies within the learned world itself, he stipulated that the congress should take place not in Paris, but in a free German city like Frankfurt, since Germany had no literary capital which 'usurps the right to judge without appeal':

[La république des lettres] admet des rangs déterminés par l'admiration, l'estime, la reconnaissance; mais sans être anarchique, elle fut toujours et toujours elle doit être acéphale dans le sens étymologique de ce mot qui exclut la domination. ${ }^{19}$

The Republic of Letters admits of hierarchies determined by admiration, esteem, and recognition; but without being anarchic, it has always been and must be acephalous (headless) in the etymological sense of the word which excludes all domination.]

Grégoire's second treatise was inspired by his journeys through Germany, and was stimulated (and perhaps funded) by his Scotch correspondent John Sinclair; it was published as a pamphlet with no mention of date or publisher. Again, nothing came of the plan. There is a single reference in a provincial learned journal some thirty years later. ${ }^{20}$ His final pamphlet about the Republic of Letters, in 1824, is an angry anonymous tract, written when Restoration censorship was at its peak under the reactionary ultra government. In this Essai sur la solidarité littéraire entre les savants de tous les pays, the main message is that scholars should abstain from all kind of false honours and royal pensions in the name of cosmopolitan solidarity in the realm of learning. A lifelong inveterate opponent of slavery, he compares the Royal Academy to a slave market: 'Aux marchés de Bahia, Rio-Janeiro, la Havane, d'infortunés Africains sont vendus contre leur gré: ici sont des savants, des artistes qui se vendent librement. ${ }^{21}$

The argument in Grégoire's second treatise, that political fragmentation in the German lands is conducive to literary republicanism can also be found elsewhere. Germaine de Staël had made the same point earlier, in De la Littérature (1800), introducing French readers to 'northern literature':

Le régime féodal auquel l'Allemagne est soumise, ne lui permet pas de jouir de tous les avantages politiques attachés à la fédération. Néanmoins la littérature allemande porte le caractère de la littérature d'un peuple libre; et la raison en est évidente. Les hommes de lettres d'Allemagne vivent entr'eux en république; plus il y a d'abus révoltans dans le

\footnotetext{
${ }^{19}$ Grégoire, Plan d'Association générale entre les savans, gens de lettres et artistes, Pour accélerer les progrès des bonnes mours et des lumières [1816-17?], reprinted in Bertrand Plongeron (ed.), L'Abbé Grégoire et la République des Savants (Paris, 2001), 46, 7

${ }^{20}$ La Mosaïque de l'Ouest et du centre 1846-47, 193-5

${ }^{21}$ Grégoire, Essai sur la solidarité littéraire entre les savants de tous les pays (Paris, 1824), 19
} 
despotisme des rangs, plus les hommes éclairés se séparent de la société et des affaires publiques. ${ }^{22}$

[The feudal regime to which Germany is subjected does not permit it to enjoy all the political advantages attached to a federation. Nonetheless, German literature bears the character of the literature of a free people; and the reason for that is evident. German men of letters live among each other in a republic; the more revolting abuse of power there is within the despotism of ranks, the more enlightened men separate themselves from society and public affairs.]

This is later echoed almost word for word by the future literary historian George Ticknor, in a letter dated June 20, 1816, sent from Göttingen, where he was studying, to his father in Boston. The main difference is that Ticknor turns German political fragmentation into a positive condition, and one which sets Germany apart from other nations:

We have always been accustomed to hear and to talk of the republic of letters as a state of things in which talent and learning make the only distinction; [but] the thing itself has remained as unreal as Sydney's 'Arcadia' or Sir Thomas More's 'Utopia'. [...] In Germany, however, from the force of circumstances and character, a literary democracy has found full room to thrive and rule. Here, there can be no broad system of patronage, for the people are too poor and the governments too inconsiderable. ${ }^{23}$

According to Ticknor, German scholars 'not only feel themselves to belong to an independent body of men, but are really considered so by the several governments under which they happen to live'. ${ }^{24}$ They can move from university to university across borders, earning their bread by their talents, remote from political influences. Spreading from the Protestant lands, their Republic now extends 'from Berne to St. Petersburg, and from Munich to Copenhagen'. ${ }^{25}$

It is a somewhat idealized picture as far as academic freedom is concerned, but the mobility across universities and the early concentration of scholarship at universities in the German lands is well attested to. This fact, however, has also been interpreted differently. Friedrich Paulsen, the late nineteenth-century historian of the German educational system, compared the German universities to the uniformized Napoleonic Université Impériale because they were maintained similarly across borders, like a decentralized Reichsuniversität. ${ }^{26}$ In a 2004 article, Kasper Eskildsen claims that 'Germany left the Republic of Letters' in the

\footnotetext{
${ }^{22}$ Germaine de Staël, De la Littérature considereé dans ses rapports avec les institutions sociales ([Paris], 1800), 200

${ }^{23}$ George Ticknor, letter of 20 June 1816, in G.S. Hilliard (ed.), Life, Letters, and Journals of George Ticknor (Boston and New York, 1906 [1876-77]), Vol. I, 99-100

${ }^{24}$ Ibid., 101

${ }^{25}$ Ibid.

${ }^{26}$ Friedrich Paulsen, Die Deutschen Universitäten und das Universitätsstudium (Leipzig, ${ }^{2} 1896$ [1885]), Vol. I ch. V.3; on p. 266, Paulsen states that 'erst im 19. Jahrhundert ist der Austausch allgemein und regelmäßig geworden; alle deutschen Universitäten bilden jetzt Glieder eines einheitlichen Organismus'.
} 
early eighteenth century because German scholars, clustering at universities, stopped caring about the rest of the learned world. ${ }^{27}$ All the same, as late as 1853, the monumental (and unfinished) Ersch-Gruber Allgemeine Encyclopädie der Wissenschaften und Künste treats the 'Gelehrtenrepublik' as in no way passé, as long as it stands for learning 'nicht als Sache des Einzelnen', but as a means to elevate the nation. ${ }^{28}$ According to the article GELEHRSAMKEIT it is not really a Republic though, because it lacks a republican government; in this sense, it resembles more an aristocracy.

Another series of reconceptualizations of the Republic of Letters emerged from German Idealism in the course of its attempt to found science at large on a new set of metaphysical principles. The general tone of the argument is completely different from the tone of Grégoire, De Staël, and Ticknor. Three tracts from 1799, 1801, and 1806, argue that the previous or current chaotic state of knowledge represented by the Gelehrtenrepublik lacked a rational foundation; that it was not true knowledge; and that the Republic of Letters needs to be replaced by something better.

Thomas Thorild, a Swedish poet and critic living in exile as a professor and librarian in Greifswald, was the first to argue so in a series of essays published as Die Gelehrtenwelt in 1799. It is a bombastic and eccentric work, in which Thorild casually compares himself to Socrates and Bacon, owing to his discovery that there can be neither true knowledge nor religion nor critique without an initial determination of Maximum, against which all arguments can be measured (Die Gelehrtenwelt accompanies a larger work in Latin indeed titled Maximum). On the state of the Republic of Letters, Thorild is rather brief: all the knowledge that the Gelehrtenwelt has so far gathered and circulated is void.

Albrecht Hummel, an untenured legal scholar in Göttingen, dwelled at much greater length on the Republic of Letters in Über den gegenwärtigen Zustand der Gelehrtenrepublik und der akademischen Lehranstalten (1802). The picture he paints is grim: the Republic of Letters is in a state of anarchy, everyone shouting and pursuing their own opinions, filling journals for the sake of vanity. In the name of rationality, a new social contract is needed.

Der Verfasser hat sich seit mehrern Jahren immer fester von der Wahrheit der Behauptung überzeugt, daß die sicherste, schnellste und gewisseste Harmonie in dem bisher so vernunftwidrigen Laufe der Dinge in der Welt vorzüglich dadurch bewirkt werden könnte, daß die ganze Gelehrten-Republik durch einen Machtspruch als Gesellschaft aufgelöst und jedes bisherige Mitglied derselben seinen förmlichen Abschied so lange erhalten würde, bis ein neuer gesellschaftlicher Vertrag errichtet wäre, vermöge dessen nur Geisteskraft, Konsequenz im Denken und Handeln und wahre Geistes-Süperiorität zur aktiven Mitgliedschaft in dieser ganz neu belebten und neu organisirten Korps berechtigen könnten. ${ }^{29}$

\footnotetext{
${ }^{27}$ Kasper Risbjerg Eskildsen, 'How Germany Left the Republic of Letters', Journal of the History of Ideas 65:3 (2004), 421-32

${ }^{28}$ K.H. Scheidler, 'GELEHRSAMKEIT (Gelehrt und Gelehrter, Gelehrtenstand, Gelehrtenherrschaft und Gelehrtenrepublik)", Allgemeine Encyclopädie der Wissenschaften und Künste Vol. 56 (Leipzig, 1853), 413-24: 423

${ }^{29}$ Albrecht Hummel, Über den gegenwärtigen Zustand der Gelehrtenrepublik und der akademischen Lehranstalten (Berlin, 1802), 41
} 
[The author has been convinced more and more over several years of the truth of the assertion that the surest, fastest, and most certain harmony in the course of affairs in the world still so contrary to reason can best be achieved by dissolving the entire Republic of Letters through an edict, granting each former member formal leave until a new social contract has been established, by force of which only power of mind, consistency of thought and action, and true intellectual superiority would entitle one to membership in this newly organized corps.]

Such a reorganization is now possible, according to Hummel, 'durch die genialische Darstellungen des Erfinders der Wissenschaftslehre und der Naturphilosophie', that is, through the works of Fichte and Schelling, who have shown that knowledge is really possible. $^{30}$

A few years later, in his lectures on Die Grundzüge des gegenwärtigen Zeitalters (delivered 1804-1805, published 1806), Fichte would present that reorganization as a historically inexorable development. Fichte outlines a model of history with five stages, of which Gelehrtenrepublik is the middle stage in the emanation of Vernunft. In the first stage, partly a somewhat Rousseauist state of nature, partly an idealized image of Hellas, all instinctively pursue their Vernunft; in the second (medieval) stage they are subjected to authority, reason thus becoming the privilege of the few; in the third stage authority is thrown off, but reason gets lost in the clamour; in the fourth stage, reason spreads in the form of Wissenschaft; and in the fifth stage, life and the world are shaped accordingly. ${ }^{31}$ Fichte then asks whether we are already entering the fourth stage or we are still at the end of the third; Aufklärung, according to Fichte, is 'durchaus negativ' and the Gelehrtenrepublik only a selfpropagating stream of opinion and compilation, Druckenlassen and Leserei. ${ }^{32}$ Man's innate potential for reason can only be realized through self-awareness, individually through Bildung, and collectively through Wissenschaft. In the subsequent Reden an die deutsche Nation, Fichte reformulates the problem as one of popular education; the Republic of Letters, as a self-contained community, serves only the self-realization of the few and not of the nation or mankind. ${ }^{33}$

One text at least opposed such totalitarian tendencies. The Bonn professor of medicine, Christian Harleß, made an appeal to a more robust Gelehrtenrepublik. Under the title 'Der Republikanismus in der Naturwissenschaft und Medizin', Harleß addressed not the learned world at large, but only a segment; and in the name of the republican scientific spirit, he sought to expel dogmatic systems, idiosyncratic amateur opinion, and pseudoscience. Interestingly, this text was the inaugural statement - after a four-year interval - of the Neue (Rheinische) Jahrbücher der teutschen Medicin und Chirurgie, a journal that could be classified as 'semi-specialist', addressing as it did developments in a particular field, but unlike later professional journals, was filled mainly by Harleß himself.

\footnotetext{
${ }^{30}$ Ibid., 59

${ }^{31}$ J.G. Fichte, Die Grundzüge des gegenwärtigen Zeitalters (Berlin, 1806), 18-19

${ }^{32}$ Ibid., ch. 6

${ }^{33}$ Fichte, Reden an die deutsche Nation (Berlin, 1808), 315-6. Cf. David James, Fichte's Republic: Idealism, History and Nationalism (Cambridge, 2015), 32-40, 146-59
} 
Scientific republicanism, for Harleß, stood in opposition to every sort of monarchy, aristocracy, oligarchy, anarchy, decadence, and despotism. It pitted freedom of research, teaching, and opinion against 'the despotism of dogma and sectarian spirit', ${ }^{34}$ an informed eclecticism against doctrinary systems, lazy syncretism, and straight-out unphilosophical empiricism. ${ }^{35}$ The dictatorship of authority and opinion ('Systemherolde und Meinungsdespoten') was thus to be avoided at all costs. ${ }^{36}$ But at the same time, in Harleß' Republic of Letters the spirit of toleration did not extend everywhere. He distinguished between the true and the false 'priests of Isis', ${ }^{37}$ and called for 'open and manly war' against 'Sectirerei, Soloecismus und Obscurantismus, Geheimnis- und Arcanensucht, Pfuscherei, Quacksalberei und andere niedrige Volkstäuschung' as well as for 'Enthüllung und Ausrottung des Aberglaubens, der Schwärmerei, Romantik, Mystik, und anderer Auswüchse' ${ }^{38}$

On the whole, the Republic of Letters was not a seminal figure of thought for German Idealism or the Early Romantic movement. Other texts which sought to annex the world of learning for a philosophical agenda, of which they produced quite a few, did not use the same rhetorical image of a scattered, ailing Gelehrtenrepublik. The phrase returned, however, in polemics surrounding the Hegelian Jahrbücher für wissenschaftliche Kritik in the late 1820s and 1830 s, discussed below.

Whereas both Grégoire's pamphlets and those issuing from German Idealism are loudly programmatic, the most extensive British post-revolutionary reflection on the subject assumes a rather detached tone. Isaac D'Israeli's An Essay on the Manners and Genius of the Literary Character (1795), though written at age 29, reads like the nostalgic work of an old bibliophile, which D'Israeli (father to the future prime minister) duly became. The virtues extolled are politeness and quiet resignation. Solitude, with a capital S, is described as a necessary condition for literary activity. Occasional poverty and disdain is stoically shrugged off as a fact of literary life (not, for sure, of his life). Nor is it even necessary, according to D'Israeli, for men of letters to actually write; they can be good patrons or conversationalists instead. On the other hand, he strictly delineates the true author from the mere scribbler: "no Writer, has a just claim to the title of Author, whose CHIEF EMPLOYMENT is not that of STUDY and COMPOSITION. ${ }^{39}$ Accordingly, one of the greatest threats to the literary character is the multitude of books now pouring forth, and the only appropriate response is not to seek fame: 'he who would be reverenced as an author has only one resource; and that is, by paying to himself that reverence, which will be refused by the multitude. ${ }^{40}$ All in all, there is not much republican sentiment in the essay. Although D'Israeli speaks of a Republic of Letters repeatedly, his more poignant image is quite the opposite: 'Houseless wanderers, scattered and solitary'. ${ }^{41}$ Only towards the end does he come to address the political influence of men

\footnotetext{
${ }^{34}$ Christian Harleß, 'Der Republikanismus in der Naturwissenschaft und Medizin', Neue Jahrbücher der teutschen Medicin und Chirurgie I.2 (1819), 1-89: 13

${ }^{35}$ Ibid., 37

${ }^{36}$ Ibid., 51

${ }^{37}$ Ibid., 17

${ }^{38}$ Ibid., 55

${ }^{39}$ Isaac D'Israeli, An Essay on the Manners and Genius of the literary Character (London, 1795), 3

${ }^{40}$ Ibid., xvi

${ }^{41}$ Ibid., 2
} 
of letters, and that mainly by virtue of their detached reflection. In the final chapter, he argues for 'an academy of polite literature, or belles-lettres', so that men of letters can combine their forces to compile dictionaries, and ailing poets can be protected by royal pensions.

In 1829 Samuel Taylor Coleridge wrote what is probably the longest and most outspoken text in English about the role of the learned community: On the Constitution of the Church and State. Coleridge, however, wishes to see them united in a different way: in a 'National Church' that guards culture and education, and that abstains from all worldly power. With a pseudo-archaic neologism, he describes the members of this monastic learned commonwealth not as 'men of letters', but as the 'Clerisy', in what is effectively a mix of medieval monasticism and the early modern Republic of Letters:

The CLERISY of the nation [...] or national Church, in its primary acceptation and original intention, comprehended the learned of all denominations, the sages and professors of the law and jurisprudence, of medicine and physiology, of music, of military and civil architecture, of the physical sciences, with the mathematical sciences as the common organ of the preceding; in short, all the so called liberal arts and sciences, the possession and application of which constitute the civilization of a country, as well as the theological. ${ }^{42}$

Coleridge's tract came at a moment of both religious and educational rupture; it was a response to the 1828 Catholic Bill that emancipated Catholicism in England, and coincided with the debates that surrounded the foundation of London University and of King's College, which broke the Oxbridge duopoly and opened higher education to all confessions.

Coleridge's main concern is with national education: the task of the Clerisy is 'to provide for every native that knowledge and those attainments, which are necessary to qualify him as a member of the state, the free subject of a civilized realm'. ${ }^{43}$ Unlike the 'lecture-bazaars under the absurd name of universities', the national church has to educate man as a whole, morally as well as intellectually, for 'we must be men in order to be citizens' ${ }^{44} \mathrm{With}$ this insistence on national education and citizenship Coleridge, in spite of his medieval theocratic fantasies, speaks the language of the French Revolution; elsewhere, he speaks passingly of a 'national institute'.

While Coleridge's idiosyncratic ideas caused the few explicit commentators on his tract to shake their heads in despair, ${ }^{45}$ he exerted a detectable influence on a range of conservative reformists in the 1830s, including Tory-turned-Liberal statesman William Gladstone, Christian Socialist F.D. Maurice, and Rugby School Headmaster Thomas Arnold, who all wrote books about church and state in the 1830s. ${ }^{46}$ John Stuart Mill, while subscribing to Coleridge's idea of national education that goes beyond basic instruction, speaks of 'the most

\footnotetext{
${ }^{42}$ S.T. Coleridge, The Constitution of the Church and State, according to the Idea of Each; with aids towards a right judgment on the late Catholic Bill (London, 1830 [1829]), 47

${ }^{43}$ Ibid., 77

${ }^{44}$ Ibid., 70,45

${ }^{45}$ Thus the Eclectic Review 3:IV (July 1831), 1: 'he dives deep, but comes up muddy'.

${ }^{46}$ Gladstone, The State in its Relations with the Church (London, 1838); Maurice, Has the Church or the State power to educate the Nation? (London, 1839); Arnold, Principles of Church Reform (London, 1833). Cf. John Colmer's introduction to Coleridge, Constitution (Collected Works 10; Princeton, 1972), lviii-lxviii
} 
able and accomplished of the rising defenders of the Church of England', who 'have evidently issued from Coleridge's school, and have taken their weapons chiefly from his storehouse'. ${ }^{47}$

'Clerisy', as a neologism, can be regarded as an attempt to redefine the learned Republic by giving it a new name, but also as a rival term that takes over part of its functions. The same holds true for the slightly later, and ultimately more successful, term 'Intelligentsia', which was adopted by Russian revolutionaries and invoked in the 1848/49 Frankfurt Parliament. The parallels with Coleridge are remarkable, even though the political agenda associated with 'intelligentsia' is completely opposite. Polish nationalist thinker Karol Libelt, who later sat in the Frankfurt Parliament, defined the 'national intelligence' (inteligencya narodu) in a tract about 'Love of the Fatherland' as 'All those who having carefully and broadly obtained an education in higher schools and institutes, stand at the head of the nation as scholars, officials, teachers, clergymen, industrialists - in sum all those who lead it because of their higher enlightenment'; ${ }^{48}$ in subsequent (mainly Russian) usage, it became a denominator especially for poor, independent authors, exiles, and revolutionaries. ${ }^{49}$

The two main differences of both with early modern conceptions of the learned community are obvious. First, the main obligation was not towards fellow scholars but towards the nation - a different 'imagined community'. Second, these particular obligations singled out particular segments of the learned world: no matter how inclusively 'Clerisy' and 'Intelligentsia' were defined, the terms addressed the chosen few, and even without language barriers, few would have self-identified as a member of both. In the next section, we shall see a similar pattern of journals appealing to the Republic of Letters while representing a distinct segment, party, or ideology. This segmentation was not in itself a new phenomenon; the learned Republic had always been kept together by strife. One divisive factor that stymied post-Revolutionary attempts to redefine the Republic of Letters was not the lack of a common goal, but the fact that such redefinitions involved more substantial, and therefore more exclusive, conceptions of that common goal.

\section{The Role of Learned Journals}

The number of learned journals in the early nineteenth century runs in the thousands; an 1839 article on 'Das deutsche Journalwesen' mentions 868 for the German lands alone. ${ }^{50}$ Most of these were short-lived, and only a small number could count as centres of learned discussion not accidentally, those that were also most likely to review foreign works. Much of the discussion about the Republic of Letters is related to the role of journals, and therefore we see a concentration of journals in periods wrought with journalistic changes: the 1790s in France, the 1800s in Britain, and the late 1820s and 1830s in Germany.

\footnotetext{
${ }^{47}$ [J.S. Mill], 'Corporation and Church Property', The Jurist IV (Feb. 1833), 1-26: 25. Cf. Ben Knights, The Idea of the Clerisy in the Nineteenth Century (Cambridge, 1978), 156-7

${ }^{48}$ Karol Libelt, 'O Miłocy Ojczyzny' [1844], in id., Rozprawy o odwadze cywilnej, miłości ojczyzny, wychowaniu ludów (Cracow, 1869), 65-160: 112, as quoted in James Billington, Fire in the Minds of Men: Origins of the Revolutionary Faith (New York, 1980)

${ }^{49}$ Cf. Christophe Charle, Les Intellectuels en Europe au XIXe Siècle: Essai d'histoire comparée (Paris, 1996), 246-55; Isaiah Berlin, Russian Thinkers (ed. H. Hardy \& A. Kelly) (London 1978), 114-35

${ }^{50}$ W.M. [Wolfgang Menzel], 'Das deutsche Journalwesen”, Deutsche Vierteljahrsschrift I:5 (1839), 1-32
} 
The afterlife of the Republic of Letters begins in 1794-1795 rather than in 1800. After the fall of Robespierre, the post-Thermidorian Directoire set about creating a national system of education and reorganizing scientific institutions, as had been proposed before the Reign of Terror. The editors of the Séances des écoles normales, a series of proceedings devoted to the secondary education curriculum, jubilantly exclaimed:

République des lettres; nous sortons des tombeaux! [...] Déjà nous preparions de nouveaux essais, une création sociale, pour assurer l'indépendance de la République des Lettres, et délivrer les amis de la vérité, du plus honteux esclavage, quand de nouveaux obstacles, à cause de la désorganisation dévorante où nous sommes, ont entravé les meilleurs desseins. $^{51}$

[Republic of Letters: we rise from the tomb! (...) We are already preparing new essays, a social creation, to assure the independence of the Republic of Letters and deliver the friends of truth from the most shameful slavery, while new obstacles, caused by the devouring disorganization in which we find ourselves, have hampered the best designs.]

In the first four paragraphs of the Law on Public Instruction of 3 Brumaire, An IV (25 October 1795), also known as the 'Loi Daunou', a complete national system of education is laid out, from bottom to top: 1. Écoles primaires, 2. Écoles centrales, 3. Écoles spéciales, 4. Institut national des sciences et des arts. ${ }^{52}$ The Écoles speciales replaced the universities, which over the past five years, as vestiges of the Old Regime, had been stripped of their privileges and endowments, emptied by the general call to arms, and finally abolished. The old royal academies were reshuffled into classes at the Institut National, and reinstated at the apex of the pyramid. ${ }^{53}$ Established as the arbiter of the learned world in France, and determined to become so in the learned world at large (one German tract called it 'diesem höchsten Tribunal, das die gelehrte Welt für Talente und Gelehrsamkeit, für Tiefsinn und Scharfsinn kennt'), ${ }^{54}$ the Institut National also became the centre of learned journalism. The Journal des Savans, which had ceased in 1792, opened again in early 1797 with a Coup-d'Eil general sur l'état des lettres, des sciences et des arts en Europe. It was, however, unable to sustain itself without royal patronage. The gap was filled by three other journals that were filled mainly by members of the Institut: the Mercure de France, Magasin Encyclopédique, and Décade Philosophique.

What these journals had in common is that they covered academy proceedings, foreign literature, and a broad range of literature and sciences. They did so with different agendas. The Décade (named after the revolutionary ten-day week) was the organ of the Idéologues, who dominated the new class of Sciences morales et politiques at the Institut. 'Ideology', in the original sense, was a theory of knowledge that rooted all sciences in the 'science of ideas',

\footnotetext{
${ }^{51}$ [Nicolas de Bonneville (ed.)] Séances des écoles normales, Pt. I Vol. IV (Paris, An IV [1795]), appendix, p. 1

52 In: James Guillaume, Procès-verbaux du Comité d'instruction publique de la Convention nationale, Vol. VI (Paris, 1867), 793-800

${ }^{53}$ R.R. Palmer, The Improvement of Humanity: Education and the French Revolution (Princeton, 1985), 105-6

${ }^{54}$ Franz Xaver von Zach, Über Johann Carl Burckhardt ([Gotha], 1801), 6
} 
and sought to cleanse them of false ideas and misperceptions. In its reporting, the Décade followed the order of the classes of the Institut - natural sciences, moral sciences, literature, and beaux-arts - concluding with political news. In 1807, after previous curtailment, it was merged forcibly with the Mercure, by then its political opponent.

The Mercure de France had a long history as a literary and fashionable journal under the Ancien Régime, and it remained more literary in outlook than the Décade and Magasin.

Reappearing in 1795 as the Mercure Français, it aligned itself with the Institut while arguing for the unity of sciences, arts, and letters:

Pendant long-tems les sciences ont eu leurs journaux à part, et ces journaux n'étaient guères lus que du petit nombre de savans qui les cultivaient. Par un préjugé nuisible aux progrès de l'esprit humain, la république des lettres formait autant de départemens qui se regardaient comme isolés, et trop souvent étrangers les uns aux autres. Mais à mesure que l'on a mieux senti les rapports qui existent entre toutes les connaissances, et les secours mutuels qu'elles peuvent se prêter, ces limites exclusives ont disparu; et puisque les sciences, les arts et les lettres sont aujourd'hui réunis dans le même temple, ils doivent l'être aussi dans les journaux qui sont les dépositaires du culte qui leur est rendu. ${ }^{55}$

[For a long time the sciences have had their separate journals, and these journals have hardly been read except by the small number of scholars that cultivated them. By a prejudice that hindered the progress of the human spirit, the Republic of Letters formed as many departments which regarded themselves as isolated, and too often strangers to each other. But in so far as the bonds that exist between all kinds of knowledge have been better recognized, as well as the mutual support that they could render to each other, these exclusive limits have disappeared; and since the sciences, arts, and letters have been reunited nowadays in the same temple, so they must also be in the journals which are the depositories of the worship delivered to them.]

In this re-opening statement, the Mercure committed itself to restoring the esprit de critique that had gone missing when 'freedom fell prey to anarchy', and to offering its readers a tableau of the spread of Enlightenment, the main political events, and the state of opinion throughout Europe. Around 1800, it became increasingly the organ of royalism and classicism, and was owned briefly by Chateaubriand. In 1811, it was forced to cease publication, and reappeared from 1815-1825.

The Magasin Encyclopédique was less politically outspoken than its rivals; but it, too, had to reinvent and rename itself several times during the Restoration, becoming in turn the Annales Encyclopédiques (1816-1817) and the Revue Encyclopédique (1818-1835). As its subtitle indicated, its aim was to offer an overview of 'des productions les plus rémarquables dans la littérature, les sciences et les arts'. After 1818, it did so in the form of 1 . shorter notices, 2. mémoires (including independent papers), 3. nouvelles from the learned world, 4.

\footnotetext{
55 'Vues générales sur le nouveau plan de ce journal', Mercure Français XX:19 (10 Nivôse, An IV [31 December 1795]), 3-13: 5
} 
notices of the proceedings of academies and societies, French and foreign. When, in late 1827, the reactionary Ultra government was ousted, and censorship loosened, the January 1828 issue of Revue Encyclopédique opened with a 'Considerations générales sur la république des lettres, en 1827 ', in which they proclaimed the Republic of Letters to be more lasting than any despotic regime:

Ainsi, la Revue Encyclopédique demeure irrévocablement attaché à toute la république des lettres, quelles que soient les chances de bonne ou de mauvaise fortune réservées dans l'avenir à cet État sans gouvernement, sans armées, et qui ne manque point d'ennemis. Malgré son apparente faiblesse, cette république est plus sûre de sa durée que les empires les plus puissans: elle subsistera aussi long-tems que la raison humain; et à toutes les époques, son étendue sera la véritable mesure de la civilisation sur toute la surface de la terre, et dans chaque nation. ${ }^{56}$

[Therefore, the Revue Encyclopédique remains irrevocably attached to the entire Republic of Letters, whatever may be the chances of good or bad fortune reserved in the future for that State without government, without armies, and not lacking in enemies. In spite of its apparent weakness, this republic is more sure of its survival than the most powerful empires; she subsists as long as human reason; and in all ages, her extent will be the true measure of civilization all over the Earth's surface, and in each nation.]

Rather than aligning itself exclusively with the Institut, the article mentioned learned societies in general as a bastion to preserve the Republic of Letters, and expressed the hope for more alignment and cooperation between them, both Parisian and regional academies, and those abroad.

The statutes of the Journal des Savants, re-founded by Pierre Daunou in 1816, explicitly declared it unpolitical. It distinguished itself by identifying reviewers with full namessomething rare in earlier learned journals - and by positioning itself as the counterpart of the Institut's proceedings, poised to pass judgment on the most relevant scholarly works.

Accordingly, in its orientation it is more specialist and less public oriented than the Mercure, the Magasin, or the Décade, and more focused on the international scholarly community. (In its first years, more than half the works reviewed are foreign.) Moreover, the reviews in the Journal des Savants were considerably longer, appearing each month compared with the 10day cycle of the Décade and bi-monthly Mercure.

In 1824, the journal Le Globe was the first to establish a prominent intellectual platform independent from the Institut. Filled by a group of liberal-minded intellectuals ('Doctrinaires') that included the young Sainte-Beuve, it maintained symbiotic relations with the new generation of historians emerging in the 1820s - Guizot, Thiers, Barante, Augustin Thierry - and championed artistic freedom against 'l'oligarchie des academiciens' ${ }^{57}$ In three

\footnotetext{
56 'Considerations générales sur la république des lettres, en 1827', Revue Encyclopédique 37 (January 1828), 514: $9-10$

${ }^{57}$ Jean-Jacques Goblot, La jeune France libérale: Le Globe et son groupe littéraire, 1824-1830 (Paris, 1995), $262 \mathrm{ff}, 371 \mathrm{ff}$
} 
issues weekly $(4+4+8 \mathrm{pp}$.), it covered national and international literary news 'sans toutefois entrer dans des discussions trop profondes', but also without frivolities and 'esquisses parisiennes', ${ }^{58}$ with the goal of reaching a wider learned audience than the Revue Encyclopédique. In each issue foreign books were discussed first, amounting to ca. $40 \%$, predominantly English publications, the rest covering other European countries, the United States, and, especially, French and English works about the rest of the world. ${ }^{59}$ Goethe formulated his concept of Weltliteratur in immediate response to reading Le Globe. ${ }^{60}$ After 1827, Le Globe reshaped itself as a political journal, and after the July Revolution, it lost most of its original contributors and was sold. Part of its role and some of its key authors were taken over by the monthly/fortnightly Revue des deux Mondes, which devoted, at least in its first decade, most of its pages to foreign affairs and voyages, alternating between - or mingled with-literature and politics; news about both were also summarized at the end of each issue in the Chronique littéraire and Révolutions de la quinzaine. ${ }^{61}$

In the United Kingdom, around 1800, there was a split at the high end of the journalistic landscape. On the one end, there were the Royal Society's Transactions and smaller scholarly journals linked to learned societies; on the other end, there was a range of more broadlyoriented monthlies and reviews following in the footsteps of the Monthly Review (1749-1844). The selling points of the Monthly and its main rival, the Critical Review, were that they covered the book market as a whole, including poetry, novels, and theatre; that some contributions went beyond mere book notices and summaries; and that, after an initial Grub Street phase, they amassed a growing pool of expert reviewers. ${ }^{62}$ Pennsylvanian theologian Samuel Miller, in A brief retrospect of the eighteenth century (1803), noted how 'the Reviews of the last age [...] have contributed to give a new aspect to the republic of letters' by taking it out of the philosopher's study. ${ }^{63}$ In the same year, The British Essayist proudly proclaimed: 'We consider the republic of letters under obligations to us for its very existence, for how could it be a republic, unless its members were kept upon an equality with each other? ${ }^{64}$

There was no perceived gap or crisis in British learned journalism when the Edinburg Review first appeared in 1802. But the Edinburgh reviewed selectively, rather than comprehensively, with a slower cycle; it offered for more space (30-40 pages or more against 3-5); and it paid much better (10-25 guineas per sheet against 2 guineas). Intellectually, it manifestly set forth the agenda of the Scottish Enlightenment, speaking out on such issues as natural science and its popularization, philosophical history, and abolitionism. ${ }^{65}$ One of its founders was the future historian and Whig Lord Chancellor, Henry Brougham. As its

\footnotetext{
${ }^{58}$ Le Globe: Journal littéraire, prospectus, 15 September 1824, 2

${ }^{59}$ Ibid., table du tôme premier, 3-9..

${ }^{60}$ Manfred Koch, 'Geistiger Handelsverkehr. Die Metaphorik in Goethes Weltliteraturkonzept und die Tradition der Gelehrtenrepublik', in Knoche\&Santini (eds.), Die europäische République des Lettres, 124; cf. Heinz Hamm, Goethe und die französische Zeitschrift Le Globe: Eine Lektüre im Zeichen der Weltliteratur (Weimar, 1998), 13-42

${ }^{61}$ Cf. Gabriel de Broglie, Histoire politique de la Revue des Deux Mondes, de 1829 à 1979 (Paris, 1979), 19-60

${ }^{62}$ Derek Roper, Reviewing before the Edinburgh, 1788-1802 (London, 1978), 19-36

${ }^{63}$ Samuel Miller, A brief Retrospect of the Eighteenth Century (New York, 1803), Vol. II, 238. Miller also spoke of an 'American republic of letters' (56n) and noted 'the rise of several nations from obscurity in the republic of letters' (302)

${ }^{64}$ The British Essayist XLIII (1803), 90

${ }^{65}$ Groffy, Die Edinburgh Review, passim
} 
political profile became more outspokenly Whig, its success motivated prominent Tories, including erstwhile contributor Walter Scott, to found the competing Quarterly Review (18091962) in its mirror image. ${ }^{66}$

While the Edinburgh devoted more attention to natural science and was marginally more internationally oriented (around one third against one quarter of the works reviewed in the period until 1830) - both reviewed the same range of foreign authors (De Staël, A.W.

Schlegel, Sismondi, Chateaubriand), and both had an uneasy relation with Keats, Shelley, and the Lake Poets. The Edinburgh reviewed De Staël a full eight times, proclaiming her 'decidly the most eminent literary female of her age' and, after her death, 'the most brilliant writer that has appeared in our days' ${ }^{67}$ Reviews of German works often carried complaints about pedantry and metaphysical mysticism, and were mainly restricted to translations.

Nevertheless, a two-part review of Goethe's Dichtung und Wahrheit in 1816-1817 began with a long reflection on the rapid emergence of German literature. ${ }^{68}$

Although contributions to the Edinburgh and Quarterly were anonymous, on the principle that each author should carry the authority of the entire journal, they defined, more than any British institution, two schools of political-historical thought - which for the Edinburgh included Brougham, Macaulay, and J.S. Mill. All three later brought out their collected contributions to the Edinburgh as books, thus emphasizing the status of these texts as independent literary products. ${ }^{69}$ For James Mill, the Edinburgh and Quarterly were two sides of the same establishment, and he loudly decried them as such in the first issue of his and Bentham's Radical/Utilitarian Westminster Review (1824). ${ }^{70}$ Party allegiances, however, were not hewn in stone: J.S. Mill had helped draft his father's attack upon the Edinburgh and yet took up writing for it; Carlyle, also an Edinburgh and Westminster reviewer, belonged to no party but his own.

In Germany, the publication cycles of learned journals were much shorter than in France and Britain: the Göttingische gelehrte Anzeigen and the various Literaturzeitungen all appeared every two days or twice a week, so that reviews were generally spread out over consecutive issues, and on average each issue contained only two. They were less profiled than their French and British counterparts, and linked to the larger universities: Göttingen, Jena, Halle, Leipzig. Their scope was encyclopaedic: they sought to cover everything that came on the German market (i.e., what was presented at the Leipzig and Frankfurt book fairs); their style of reviewing was generally that of a summary followed by corrections and technical commentary. Dissatisfaction with this format was what stimulated the foundation of all major new journals in the early nineteenth century, along with (in the case of Heidelberg and Berlin), a desire for an organ of their own.

\footnotetext{
${ }^{66}$ Cf. Alvin Sullivan, British Literary Magazines: [II.] The Romantic Age, 1789-1836 (Westport, 1983), 137-42, 359-66; John Clive, Scotch Reviewers: The Edinburgh Review, 1802-1825 (London, 1957)

${ }^{67}$ [James Mackintosh], 'Mad. de Staël sur la Littérature', Edinburgh Review XXI (February 1813), 1-50: 3; 'Mad. de Staël sur la Révolution Française', ER XXX (September 1818), 275-317: 275

${ }^{68}$ [Francis Palgrave], 'Goethe's Life of Himself', Edinburgh Review XXVI (June 1816), 304-37; 'Goethe's Memoirs', ER XXVIII (March 1817), 83-105

${ }^{69}$ Macaulay, Critical and Historical Essays, contributed to the Edinburgh Review, 3 vols. (London, 1843); Brougham, Contributions to the Edinburgh Review, 3 vols. (London and Glasgow, 1856); J.S. Mill, Dissertations and Discussions, Political, Philosophical, and Historical, 2 vols. (London, 1859)

${ }^{70}$ [James Mill], 'Periodical Literature. I. Edinburgh Review', Westminster Review I (January 1824), 206-49
} 
Although the Literaturzeitungen also reviewed 'schöne Literatur', and even though some of the leading Romantics wrote for them (A.W. Schlegel, for instance, wrote nearly 300 reviews for the Allgemeine Literatur-Zeitung between 1795-1804) ${ }^{71}$ they were not where the literary debate happened; thus Weimar classicism and the Romantic revolution only marginally affected German learned journals. Only the Heidelberger Jahrbücher für Literatur, founded in 1808, was for the first decade of its existence an outspoken organ for the Romantic movement, in which Arnim, Brentano, the Grimms, the Schlegels, Jean Paul, E.T.A. Hoffmann, Tieck, and Kleist all wrote reviews and/or were reviewed. Even there, literature was just a sub-section (part of the section Philologie, Historie, schöne Literatur und Kunst). Yet, the agenda of the Romantic movement also extended to philosophy and the natural sciences (Naturphilosophie) and figured as such in the Heidelberger Jahrbücher. ${ }^{72}$ Since the Heidelberger Jahrbücher were more selective in what they reviewed, and appeared only every 3-4 weeks, contributions occasionally attained more profile as independent texts and thus were not split up across several issues; still articles (Aufsätze) as such appeared only in the first issue. ${ }^{73}$

In early 1820 , slightly more than a year after his inauguration as professor of philosophy in Berlin, Hegel presented to the Prussian minister of education, Altenstein, a proposal for a new learned journal. Modelled after the Journal des Savants, the new journal would provide the capital and its academic institutions with their own 'Recensir-Anstalt', fulfilling the need for an 'imposing literary and scientific centre in Germany'. ${ }^{74}$ It would be authoritative in a positive sense, asserting expert judgement rather than meddling in polemics; thus it should not be left to private initiative, its contributions should be works of scholarship in their own right, and they would be signed. Nothing came of the plan, but Hegel's former student Eduard Gans and the publisher Cotta revived it six years later as a private project after all, brought out and authored by a society headed by Hegel; by then Hegel had all the more need for a reviewing organ of his own, since Schleiermacher and others had blocked his entry to the Berlin Academy. ${ }^{75}$

The Jahrbücher für wissenschaftliche Kritik finally saw print from 1827 onward, and its ambition to be the new high court of the German learned world invited not only criticism, but also reflection on the state of the learned world. Most eloquently, critic and satirist Ludwig Börne mocked the journal's announcement as a betrayal of republican values: 'Die deutsche Gelehrte Welt ist ein Freistaat, und sie wird auch einer bleiben, allen Triumviraten zum Trotze. ${ }^{76} \mathrm{He}$ drew further the analogy to the Roman republic, criticizing the state of learned journalism and the general neglect of German scholars towards the wider public interest:

\footnotetext{
${ }^{71}$ Roger Paulin, The Life of August Wilhelm Schlegel, Cosmopolitan of Art and Poetry (Cambridge, 2015), 66

72 Dietrich von Engelhardt, 'Naturphilosophie im Urteil der 'Heidelberger Jahrbücher der Literatur' 1808-1832', Heidelberger Jahrbücher XIX (1975), 53-82: 56

${ }^{73}$ Sibylle Obenaus, 'Die deutschen allgemeinen kritischen Zeitschriften in der ersten Hälfte des 19. Jahrhunderts. Entwurf einer Gesamtdarstellung', Archiv für Geschichte des Buchwesens 14:1 (1974), 1-122: 49-56

${ }^{74}$ G.W.F. Hegel, 'Über die Errichtung einer kritischen Zeitschrift der Literatur' [1819/20], in Gesammelte Werke XV (eds. F. Hogemann \& C. Jamme) (Hamburg, 1990), 195

${ }^{75}$ Obenaus, 68-78; cf. Christoph Jamme (ed.), Die 'Jahrbücher für wissenschaftliche Kritik': Hegels Berliner Gegenakademie (Stuttgart, 1994)

${ }^{76}$ Ludwig Börne, Einige Wörte über die angekündigte Jahrbücher für wissenschaftliche Kritik (Heidelberg, 1827), 7
} 
Da aber in einem Freistaate weder monarchische noch aristokratische Einfluß gestattet ist, so bleibt denen, welchen die Natur selbst den Herrscherstab in die Hand gegeben, nichts anderes übrig, ihre Rechte geltend zu machen, als daß sie (literarische) Demagogen werden, und das Volk durch Lehre und Beispielen zu leiten suchen. Aber dieses zu thun, unterlassen die vornehmen deutschen Gelehrten, die Einen aus Stolz, die Andern aus Feigheit. Sie fürchten das literarische Volk, und verachten es. Aber, indem sie es fürchten, machen sie es furchtbar, indem sie es verachten, verächtlich. Darum ist in Deutschland der litterarische Pöbel so herrschend, darum füllt es mit seinen Haufen den Markt der Zeitungen aus, und bedeckt mit seinem Geschrei jede Stimme der Wahrheit und des Rechts. $^{77}$

[Since neither monarchical nor aristocratic influence is permitted inside a free state, the only way in which those whom Nature itself has given the sceptre of power can assert their rights is by becoming (literary) demagogues, seeking to guide the people through teaching as well as through examples. But German scholars neglect to do this, some out of pride, others out of cowardice. They fear the reading public, and despise it. But in fearing it, they make it frightful, and in despising it, despicable. This is why the literary rabble is so prominent in Germany, why it fills the markets with its heaps of journals, and drowns every voice of truth and justice in the noise.]

Arnold Ruge subscribed to a similar diagnosis of German critical journals and journalism, in a more sober vein, in two articles from 1831 and 1837. As a Young Hegelian, he denounced the three leading Literaturzeitungen for 'Kantianism', as well as 'indifferentism' and failure to see the revolutions of 1830 as calls for the emancipation of the 'German spirit'. ${ }^{78}$ The Heidelberger Jahrbücher and the Göttingische gelehrte Anzeigen were disqualified ex ante as 'unphilosophical' and thus lacking in any synoptic vision. ${ }^{79}$ Ruge was, in principle, sympathetic to the agenda of the Berlin Jahrbücher; yet already in 1831, he wondered what was left of it now that it no longer maintained a consistent editorial policy. Accordingly, he set his hopes on Merkur, a journal modelled on the Edinburgh Review. By 1837, however, Merkur had ceased to appear, and now only the Berlin Jahrbücher were able to get beyond the Äusserlichkeit of literary life and feel the 'life pulse of its inner soul', albeit losing itself in fragmentation and in 'das ewiggleiche Sein und Denken des sublimen Brahmanismus wissenschaftlich vollendeter Richter' ${ }^{80}$

Wolfgang Menzel's 1839 overview article 'Das deutsche Journalwesen', already quoted at the beginning of this section, gave another formulation to what was essentially the same judgement. There were so many journals that nobody could read all of them; 'Die Allgemeinen Literaturzeitungen, Repertorien \&c., haben zwar immer sehr umständlich und vielfältig, zum Theil auch sehr gründlich rezensirt, allein immer fehlte dabei der Totalblick,

\footnotetext{
${ }^{77}$ Ibid.

${ }^{78}$ [Arnold Ruge], 'Musterung unserer bedeutendsten kritischen Journale. Mit Rücksicht auf die Zeitumstände', Blätter für literarische Unterhaltung 87-88 (27-28 March 1831), 373-80

${ }^{79}$ Ruge, 'Unsere gelehrte kritische Journalistik', Blätter für literarische Unterhaltung 223-4 (11-12 August 1837), $905-10$

${ }^{80}$ Ibid., $909-10$
} 
die großartige Zusammenfassung und Scheidung der Massen. ${ }^{, 81}$ Owing to this fragmentation, the 'gelehrte deutsche Republik' remained an 'abgeschlossene gelehrte Aristokratie', even though the Germans were 'das wissenschaftlichste Volk der Welt'. ${ }^{82}$ Here German journals stood in dismal contrast to the Edinburgh Review and Quarterly Review, which united British literati. Only one journal - the Jahrbücher - 'strebte sichtbar nach der Tyrannis in der gelehrten Republik'; yet it locked up itself in obscure jargon, and failed to reach its goal within the learned world, let alone among the wider public. ${ }^{83}$

Looking back upon the foundation of the Jahrbücher after Hegel's and Cotta's death, Eduard Gans ruefully conceded that they had not managed to maintain their superior stance, but were reacting to the tides of scholarly publishing like any other journal. Yet he defended the idea of representing the Republic of Letters through a society of scholars:

Wie sollten die verschiedenen Parteiungen zusammengebracht, die Anarchie, die der Gelehrtenrepublik einmal eigen ist, beschwichtigt, und ein Ineinanderarbeiten bewirkt werden, daß doch unentbehrliche Bedingung schien? [...] Die deutsche Gelehrsamkeit war seit drei Jahrhunderten schon so republicanisch geworden, daß es nicht gelingen konnte, ihr mit einem Male die staatliche Autorität als Vorstand aufzustellen; eine Gesellschaft, von Gelehrten gebildet, schien mir daher einen weit größeren Erfolg zu versprechen, weil ihr Ausgangspunkt selber die Wissenschaft war, die sich durch nichts anderes vertreten läßt. ${ }^{84}$

[How should the various parties be brought together, the anarchy which is inherent to the Republic of Letters overcome, and some convergence, which seemed indispensable, be brought about? (...) German scholarship had grown so republican since three centuries, that state authority could not be made to preside over it; therefore a society formed by scholars seemed to promise much greater success, as its starting point was science itself, which will not let anything else represent it.]

\section{Phraseology}

A series of Google ngram searches, supplemented by occasional finds in early nineteenthcentury learned journals, yields several hundred other occurrences of 'Republic of Letters' and its cognates for the period 1790-1848. There is no way to make this data statistically 'clean': much depends on unsystematically digitized corpora and unreliable OCR (especially a problem with blackletter). Still, this data is infinitely much richer than the data on which traditional Begriffsgeschichte was based. The unspectacular result is that the general trend in frequency of usage is downward from the very beginning of the nineteenth century onward. In

\footnotetext{
${ }^{81}$ Menzel, 'Das deutsche Journalwesen', 5

${ }^{82}$ Ibid., 5-6

${ }^{83}$ Ibid., 6

${ }^{84}$ Eduard Gans, 'Die Stiftung der Jahrbücher für wissenschaftliche Kritik', in id., Rückblicke auf Personen und Zustände (Berlin, 1836), 228, 231
} 
French, the phrase remains more common than in English or German, which also results in a clearer gradual downward trend because there is at least a continuous line. In both French and English, the less committal 'Gens de Lettres' / 'Men of Letters' is more frequent than the stronger 'Republic' metaphor. In German, the phrase 'Gelehrtenwelt' / 'gelehrte Welt' largely replaces Gelehrtenrepublik, especially in cliché phrases from notices and obituaries.

Apart from the longer conceptualizations (that is, texts about the Republic of Letters), one can distinguish four distinct ways in which the phrase is used:

1. The first, and largest, group are the clichéd uses: an author is praised for his contributions to the Republic of Letters, bemoaned as a great loss to the Republic, has made a name for himself in the Republic, or the Republic eagerly waits for a certain work to appear. These petrified phrases mainly occur in literary notices, biographical dictionaries, and obituaries.

2. Second, there are historical uses. Most of these deal with the late seventeenth and eighteenth century, but there are also references to the Republic of Letters in Antiquity and the Middle Ages. References to the eighteenth-century learned republic occur frequently in Tableaux of eighteenth-century philosophy that culminate in the French Revolution, more often than not written from an anti-Jacobin and anti-Philosophe standpoint.

3. Third, and very interesting, is the richness of political metaphors used to describe the state of letters, drawn mainly from classical republicanism, but also influenced by the rhetoric of the French Revolution. It is alternatively (and simultaneously) called anarchic, democratic, aristocratic, oligarchic, monarchic, and despotic; the Institut National is described as 'dieses höchste Tribunal, das die gelehrte Welt kennt', ${ }^{\text {, }}$ Voltaire is called the 'consul' of the Republic of Letters; everyone who dares to publish a book is slaughtered by the reviewers as a 'Julius Caesar in the Republic of Letters'; ${ }^{86}$ translation is 'la diplomatie de la république des lettres' ${ }^{87}$ Elsewhere, there are references to 'laws', 'republikanisches Wesen', 'conseil des anciens', 'princes' and 'populace', 'citoyens', 'proletaires inconnus', 'plebeïens' and 'patriciens'; in Börne’s polemic against Hegel's Jahrbücher, we have seen 'Freistaat', 'Triumviraten', 'Demagogen', and 'der literarische Pöbel'.

4. Fourth, there are remarkably many negative portrayals of the Republic of Letters. One can distinguish three types of such criticism. First, there are the complaints about the harshness of literary life and the failure of the Republic to live up to its standards, complaints which can also be heard in the eighteenth century: the learned world is dominated by cabal, 'densely peopled with a noisy multitude', ${ }^{88}$ filled with nasty reviewers and literary despots, and 'poverty is more common in the Republic of Letters than the plague in Byzantium'. Second, there are the more typically nineteenth-century conservative complaints about the Republic of Letters as a source

\footnotetext{
${ }^{85}$ Monatliche Correspondenz zur Beförderung der Erd- und Himmels-Kunde IV (July 1801), 41

${ }^{86}$ Monthly Mirror VI (December 1809), 331

${ }^{87}$ Revue Européenne VII:25 (September 1833), 122

${ }^{88}$ Edinburgh Review LXXVIII (October 1843), 365
} 
of free-thinking, godlessness, and infamy. And finally, there is a more fundamental skepticism: the Republic of Letters does not exist.

Most of these statements exist in isolation; there is not really a post-revolutionary or Restoration era debate about the Republic of Letters as such. There is, however, a debate about the infrastructure of the learned world, particularly, as we have seen, in relation to the role of learned journals. And there is a particularly intense debate in the 1790s surrounding the re-organization of French academic institutions, which becomes, in tracts like Grégoire's, a re-invention of the Republic of Letters.

Central to this debate is the Loi Daunou already mentioned. Though only made law after Thermidor, the Loi Daunou goes back to an earlier plan for national education put forward by Talleyrand in 1792. When that plan was published, it provoked a book-length response from Isaac Haffner, a Strasbourg theology professor of moderate revolutionary and liberal theological leanings, who staunchly defended the German university model (then not widely popular) that obtained in Strasbourg, in the name of academic freedom and the unity of the sciences. The compartmentalization between Écoles spéciales proposed in the Talleyrand plan, he argued, would be detrimental for the sciences as well as for education:

Si le plan de Mr. TALLEYRAND étoit exécuté, la république des lettres présenteroit bientôt la forme d'un gouvernement aristocratique. C'est de l'Institut National que doivent émaner, comme d'un foyer de lumières et de sagesse exclusive, les loix qui seront dictées aux autres établissemens littéraires. Il sera pour la raison des gens de lettres, ce qu'est l'église pour la foi des fidèles, et ils devront se soumettre de même à l'infallibilité de ses jugemens. ${ }^{89}$

[If the plan of Mr. Talleyrand would be carried out, the Republic of Letters would soon assume the form of an aristocratic government. Laws dictated to other literary establishments would have to emanate from the National Institute as from a hearth of exclusive light and wisdom. It would be for the rationality of men of letters what the church is for the faith of the pious, and they would have to submit to its infallible judgement.]

Haffner's voice was little heard in revolutionary Paris, but his book was received better in Germany, where it was used as a main source about current developments in Christoph Meiners's 1801-1805 history of the universities. ${ }^{90}$ More significant for the French debate, however, is what the Girondin journal Les Cahiers patriotiques wrote in January 1793 about national education, a few months before the Girondins fell from power and ended under the guillotine. In an appendix to the January issue, Nicolas de Bonneville and Abbé Fauchet argued for the foundation of a 'ministry of public opinion' that would rally the Republic of

\footnotetext{
${ }^{89}$ Isaac Haffner, De l'Education littéraire, ou essay sur l'organisation d'un établissement pour les hautes sciences (Strassbourg, 1792), 310

${ }^{90}$ Christoph Meiners, Geschichte der Entstehung und Entwickelung der hohen Schulen unseres Erdtheils (Göttingen, 1801-05), Vol. I, 325-33
} 
Letters for the revolutionary cause, because La république des lettres est une et indivisible. Despots pay for spies and hacks; instead, the 'Amis de la Verité' should devote themselves to public instruction, and make all parts of the world share in 'les trésors de la génie'. With a nod to Bacon, the editors proclaimed a new Instauratio magna. ${ }^{91}$

When the Mercure Français reported about the first sessions of the Institut National, almost three years later, it made a similar, but more moderate, appeal to the Institut to establish a forum free of royal patronage, founded solely on merit, and devoted to the public interest rather than to petty rivalries, vain honours, and private interests:

Si ce corps illustre veut acquérir une grande considération, il ne doit ouvrir ses portes qu'à ceux qui auront fait leurs preuves, et dont l'opinion publique aura marqué la place d'avance. S'il est une république où l'on doive écarter toute espèce de référence ou de distinction qui n'est pas fondée sur le mérite et les talens, c'est sans doute la république des lettres. ${ }^{92}$

[If this illustrious body wants to acquire great esteem, it should not open its doors but for those who have proved their worth and whose place has been marked in advance by public opinion. If there is a republic where one can cast aside all references or distinctions not founded on merit and talent, it is without doubt the Republic of Letters.]

The Mercure rhetorically asked whether such an exclusive association of learned men would not be incompatible with republican government; quite the contrary, it argued. Such a foyer commun was essential to preserve and improve upon their efforts especially in the empirical sciences, and it could demonstrate to foreign nations that France still possessed 'une masse de savans, d'hommes de lettres et d'artistes que l'Europe entière lui doit envier' ${ }^{93}$ Further on in the same issue, reporting on foreign literature, the Mercure reaffirmed that 'la république des lettres est véritablement la république universelle. ${ }^{94}$ Such universalism, obviously, could be easily turned into chauvinism. A year later, general Napoleon wrote to a Milanese astronomer that learning belonged to all free nations, and therefore especially to France: 'Tous les hommes de génie, tous ceux qui ont obtenu un rang distingué dans la république des lettres, sont Français, quel que soit le pays qui les ait vu naître. ${ }^{95}$

In British debates, the use of the phrase 'Republic of Letters' was not only less frequent but also less high-vaulted. Goldsmith's 1762 The Citizen of the World was still regularly reprinted, a satire modelled on Montesquieu's Lettres Persanes in which the learned Republic was ridiculed as 'the most absurd that can be imagined', a state in which everyone wants to

\footnotetext{
${ }^{91}$ [Nicolas de Bonneville and Claude Fauchet], 'Appendix II: Les Directeurs de l'Imprimerie du Cercle Social, aux Amis devenus frères', La Chronique du Mois, ou Les Cahiers patriotiques, January 1793, 60-65

92 'De l'Institut National et de ses premieres séances', Mercure Français XX:19 (10 Nivôse, An IV [31

December 1795]), 13-21: 20

${ }^{93}$ Ibid.

94 'Notices et annonces: Littérature étrangère', ibid., 312-4: 314

${ }^{95}$ Napoleon Bonaparte, letter of 5 Prairial An IV, to Milanese astronomer Barnaba Oriani; reprinted in [J.R.F. de Pommereul], Campagne du Général Buonaparte en Italie (Paris, 1797), 69
} 
rule and no-one wants to serve, a 'Persian army' with a large train and few soldiers. ${ }^{96}$ Statements in British journals around 1800 were mainly about its reality and viability. Thus, in 1794 the Critical Review pleaded for a repeal of the tax on paper and the duty on foreign books, 'in the name of the Republic of Letters, a republic whose conquests have always been multiplied in proportion to the efforts of coercion against them'. ${ }^{97}$ The Monthly Review wrote in 1802 that 'The multiplication of middling authors, who merely compile, and republish the sentiments of preceding writers, is an evil which threatens the existence of the Republic of Letters'. ${ }^{98}$ Two years later, however, the European Magazine and London Review observed that its ideals had finally been realized by the establishment of free education at the Collège de France, and because of that, "we should no longer consider the 'commonwealth of learning', or 'the Republic of Letters', as metaphorical epithets'. 99

After 1812, there are almost no new mentions of the Republic of Letters in the British periodical press - or in Britain at large, apart from a series of cheap poetry and prose reprints from the 1830s called Republic of Letters. In France, one way in which the phrase remained current was through re-editions of Voltaire, Bayle, Montesquieu, Diderot, d'Alembert, and the Encyclopédie. A very curious example of reviving older texts was Pierre Chailot's Manuel du Libraire, du Bibliothécaire, et de l'Homme des Lettres (1828). Along with instructions for book-sellers, a classification of subjects, and a dictionary of belles-lettres, it offered an overview of the provinces of the Republic of Letters and the tasks of the Poet, Historian, and Journalist in it. It is an archaic work both in subject and in style - especially in that section, because large parts were taken verbatim from a collection from 1699-1701, Dom Bonaventure d'Argonne's Mélanges d'Histoire et de Littérature. There is a trail of continuity here: d'Argonne's Mélanges were reprinted in 1799, in a series of Ana, ou Collections de bon mots (a genre very typical of the earlier Republic: viz. Scaligerana, Thuana, Perroniana), and Chaillot reprinted his own work in 1840, starting the preface with an open and unapologetic admission of plagiarism. ${ }^{100}$

In the German lands, two main recurrent themes were fragmentation (and attempts at unification) and the German Sonderweg. Romantic philologist Karl Morgenstern was one of the few to refer back to Klopstock's Gelehrtenrepublik, in an 1813 lecture to students in Dorpat (Tartu) on Klopstock als vaterländischer Dichter: 'Eben so war Er es, der, im Vollgefühl dessen, was Schriftsteller für ihre Nazion sind, die von Vielen mißverstandene Idee einer Gelehrtenrepublik aufstellte, wie sie so von allen Ländern in der Welt nur in Deutschland, in der Hauptsache wenigstens, ausführbar ist. ${ }^{101}$ Philosopher Henrik Steffens, who had earlier been an important contributor to the debate that led to the creation of Berlin university, called upon the German academies, as corporations representing the learned world,

\footnotetext{
${ }^{96}$ Oliver Goldsmith, The Citizen of the World; Or, Letters from a Chinese Philosopher: Residing in London, to His Friends in the Country (Dublin, 1762), 78, 82 [Letter XX]

${ }^{97}$ Critical Review XII (1794), 551

${ }^{98}$ The Monthly Review XXXVII (1802), 43

${ }^{99}$ European Magazine and London Review XLV (June 1804), 438

${ }^{100}$ [Pierre Chaillot], Manuel du Libraire et de l'Amateur des Livres (Avignon, 1840), 1: 'Peu jaloux de la gloire de l'invention, j'ai puisé, je le déclare hautement, dans tous les ouvrages qui m'ont convenu pour faire ce petit manuel. Je l'ai composé pour ainsi dire avec des ciseaux: c'est pourquoit, je prie tous ceux qui le liront de ne pas crier au voleur'.

${ }^{101}$ Karl Morgenstern, Klopstock als vaterländischer Dichter (Dorpat [Tartu], 1814), 8
} 
to overcome the 'Zersplitterung der Nation' without imposing the sort of 'nationale Einformigkeit' prevalent in France and England:

Denn, wenn auch ein jedes Mitglied der Akademie, als einzelne Person, als Mitglied der nationalen Gelehrtenwelt keine besondere Vorzüge fodern oder erhalten darf, so muß dennoch die Corporation, als eine vom Staate sanctionirte, mit einer bestimmten Autorität hervortreten. Das Wesen der Akademien ist offenbar aristokratisch, so daß sie die nothwendige Demokratie nicht ausschließt, also nicht oligarchisch. ${ }^{102}$

[Even though every member of the Academy, as an individual, as a member of the national learned world, may not request or receive special benefits, still the corporation, as one sanctioned by the state, must proceed with a certain authority. The nature of academies is openly aristocratic, without excluding necessary democracy, hence not oligrarchic.]

The association of literary republicanism with political revolution, both in a positive and a negative sense, was not restricted to France. Friedrich Thiersch's contribution to an important 1836-1837 debate about the state of German universities speaks of 'die Sonne der literarischen Republik, die mit den heilsamen Gewächsen und Blumen auch die schädlichen und giftigen entwickelt'; from the opposite end of the spectrum, two of Arnold Ruge's correspondents praise his contributions to the Gelehrtenrepublik as expressions of a republican, German, and revolutionary spirit. ${ }^{103}$

These are isolated examples, but they show that in German usage until the mid-nineteenth century, there was ongoing critical reflection on the Gelehrtenrepublik - in wry remarks on the use of Latin as a learned language as well as in panegyrics on railroads. ${ }^{104}$ The use of République des Lettres in French, while more frequent and long-lasting, was more like a presence of the past. It is somewhat paradoxical that the afterlife of the Republic of Letters was seemingly shortest in Britain, where no Old Regime institutions were abolished, no guillotines set up, and no Corsican generals ever set foot.

\section{Conclusions}

There is no 'Lost Republic' to be reconstructed. The Republic of Letters remains an actor's category in the nineteenth century, but one that slowly goes out of use; attempts to redefine or regulate the Republic result in a confusion of tongues. Still, these attempts are part of a vibrant debate about the role of the learned community - and most of all show the widespread

\footnotetext{
${ }^{102}$ Henrik Steffens, Die gegenwärtige Zeit und wie sie geworden: mit besonderer Rücksicht auf Deutschland (Berlin, 1817), Vol. II, 701

${ }^{103}$ Friedrich Thiersch, Über die neuesten Angriffe auf die deutschen Universitäten (Stuttgart and Tübingen, 1837), 29-30; Ludwig Preller to Arnold Ruge, 2 November 1837; Karl Fröbel to Arnold Ruge, 28 January 1843; both quoted in Martin Hundt, Der Redaktionsbriefwechsel der Hallischen, Deutschen und DeutschFranzösischen Jahrbücher (1837-1844) (Berlin, 2010) Vol. I, 22, $904 \mathrm{f}$

${ }^{104}$ Archiv für Philologie und Paedagogik 5:4 (1839), 91; Verhandlungen der Stände-Versammlung des Großherzogtums Baden (1838), 220-1
} 
uncertainty about the state of the learned world. The uncertainty is also about whom to address: peers, the learned community, the reading public, the nation, or the world.

In view of the growth of the reading public and the segmentation of learning, the most plausible explanation is that the Republic of Letters watered down rather than disappeared. Even the growing number of learned societies in the nineteenth century - either linked to universities or locally rooted - points in this direction: why address an imagined community if the audience is in your lecture hall ${ }^{105}$ The problem with this plausible explanation is that it associates fragmentation with a process of slow demise, while the learned world itself was steadily growing. Accordingly, decline is not a widespread diagnosis among nineteenthcentury scholars. More often, reconceptualizations of the learned republic were not responding to a sense of slow decline but to a shock: the shock of the French Revolution and its aftermath. Fragmentation was an issue mainly vis-à-vis the German situation, and it was evaluated both positively and negatively; for Abbé Grégoire, it was even a necessary condition for the existence of a Republic of Letters.

The learned world in the early nineteenth century is a terrain vague. Although many of the institutions of modern academia were created in this period, it was only in the 1860s-1870s that the number of universities, university staff, and students began to grow exponentially, and that specialist journals took over scholarly communication. It is an interim period in which the literary field, the scientific community, and the Geisteswissenschaften took shape, but in which there was much continuity of old forms. The changes in the knowledge economy of this period are important enough to merit closer analysis; they have not been subject to network analysis like the correspondence, journalism, and academies of the early modern learned world, and nineteenth-century specialists and early modernists alike rarely cross the 1800 divide.

One aspect that merits closer attention, in particular, is the public role of scholars, and the increasing division across party lines. In the mid-eighteenth century, Enlightenment philosophes had opened new ways of addressing public opinion through scholarship, and this is a model that nineteenth-century historians and literati eagerly followed. Yet there was no nineteenth-century parti philosophique; instead, after 1789; there was a rapid crystallization of political ideologies expressed in both journalism and scholarship. These political allegiances did not entirely replace learned republicanism; as we have seen, they also gave it new platforms and a new vocabulary. Tracing the afterlives of the Republic of Letters, then, is not just mapping the reconfiguration of correspondence networks and the tides of academic publishing; it also contributes to a more political history of the Republic of Letters. Rather than inspiring nostalgia for a lost world of polite learning, smaller and (presumably) more coherent, it confronts us with the ongoing problem of positioning scholarship as both an independent and a public domain, and reminds us that the 'common good' is both a commodious catch-all phrase and an essentially contested concept.

\footnotetext{
${ }^{105}$ Much of what is discussed in the transactions of nineteenth-century societies is indeed locally oriented and/or subject-specific: cf. Wilhelm Köner, Repertorium über die vom Jahre 1800 bis zum Jahre 1850 in akademischen Abhandlungen, Gesellschaftsschriften und wissenschaftlichen Journale auf dem Gebiete der Geschichte und ihrer Hülfswissenschaften erschienenen Aufsätze, 2 vols. (Berlin, 1852); Robert de Lasteyrie [et al.], Bibliographie générale des travaux historiques et archéologiques publiées par les sociétés savantes de la France, 14 vols. (Paris, 1888-1914)
} 